\title{
Detection of Xanthomonas citri pv. viticola on grapevine by real-time PCR and BIO-PCR using primers designed from pathogenicity and xanthomonadin gene sequences
}

\author{
João Gilberto A. Villela • Patricia Ritschel - Maria Angélica G. Barbosa • \\ Kétini M. S. Baccin • Mauricio Rossato • João D. G. Maia • Marisa A. S. V. Ferreira
}

Accepted: 21 May 2019/Published online: 10 June 2019

(C) Koninklijke Nederlandse Planteziektenkundige Vereniging 2019

\begin{abstract}
Grapevine bacterial canker caused by Xanthomonas citri pv. viticola (X. campestris pv. viticola) (Xcv), was detected in Brazil in 1998 and is currently regarded as a quarantine disease with limited distribution in the country. To improve sensitivity and speed in the detection of Xcv in asymptomatic grapevines, two pairs of primers were designed, targeting sequences of a pathogenicity gene $(h r p B)$ and the xanthomonadin coding cluster. Both pairs were tested in conventional PCR (cPCR) and real-time PCR (qPCR) formats. Primers targeting the $h r p B$ gene showed cross reactions with other Xanthomonas spp. but were effective for use in both cPCR and qPCR, whereas primers for the xanthomonadin gene were highly specific for
\end{abstract}

Electronic supplementary material The online version of this article (https://doi.org/10.1007/s10658-019-01779-y) contains supplementary material, which is available to authorized users.

J. G. A. Villela · M. Rossato • M. A. S. V. Ferreira $(\bowtie)$

Departamento de Fitopatologia, Universidade de Brasília, Brasília, DF, Brazil

e-mail: marisavf@unb.br

P. Ritschel · K. M. S. Baccin

Embrapa Uva e Vinho, Bento Gonçalves, RS, Brazil

M. A. G. Barbosa

Embrapa Semiárido, Petrolina, PE, Brazil

K. M. S. Baccin

Universidade de Caxias do Sul, Caxias do Sul, RS, Brazil

J. D. G. Maia

Embrapa Uva e Vinho, EVT, Jales, SP, Brazil
Xcv but showed low efficiency in qPCR. Enrichment of plant extracts in semi-selective medium before qPCR allowed a significant increase in sensitivity when compared to total DNA extraction, making it possible to detect as low as $10^{1} \mathrm{CFU} \mathrm{m}{ }^{-1}$. Under natural infection conditions, symptomatic and asymptomatic grapevines were tested by qPCR with $h r p B$ primers and cPCR with xanthomonadin primers. In both cases, plant extracts were enriched for $36-72 \mathrm{~h}$. Xcv was detected in all symptomatic samples by qPCR and the result was confirmed by cPCR. For the asymptomatic samples, Xcv was detected in $93.4 \%$ with qPCR and in $89.5 \%$ with cPCR. These two methods offer advantages in terms of sensitivity and specificity, and they could be useful in quarantine programs, certification of grapevine propagating material and detection of inoculum sources in alternative hosts, contributing to the prevention of pathogen spread to disease-free areas.

Keywords Grapevine bacterial canker. Vitis vinifera . Xanthomonas campestris pv. viticola. PCR-based diagnosis · qPCR

\section{Introduction}

Grapevine bacterial canker was detected in northeastern Brazil in 1998, affecting plants of the table grape variety Red Globe in the irrigated areas of the São Francisco river valley, (Malavolta Junior et al. 1999; Lima et al. 1999). The causal agent was identified as Xanthomonas campestris pv. viticola (Nayudu) Dye. Several studies 
based on multilocus sequencing and whole genome analysis (Parkinson et al. 2009; Midha and Patil 2014; Ferreira et al. 2019) indicated that this pathovar belongs to the $X$. citri species, and a proposal for reclassification as $X$. citri pv. viticola $(\mathrm{Xcv})$ has recently been suggested (Gama et al. 2018). Xcv is a regulated pathogen and subject to an official control program according to Brazilian legislation (MAPA 2014).

Early diagnosis of plant diseases is a crucial step for disease control and protection of agriculture. The diagnosis of bacterial canker is based on the evaluation of symptoms, isolation of the pathogen in culture medium followed by its identification using a series of tests that may include biochemical and nutritional tests, pathogenicity on grapevine, hypersensitivity reaction on tomato leaves, serology, rep-PCR, and/or species-specific PCR (Araújo et al. 2005; Trindade et al. 2005, 2007). However, these methods rely on culturing and have low sensitivity for early detection of Xcv in asymptomatic grapevine material due to low populations present in plant tissues (Trindade et al. 2007).

In recent decades, rapid, specific and sensitive DNAbased methods have been made available for the detection of pathogens in plant material (Vincelli and Tisserat 2008). PCR and its variations, such as BIO-PCR and real-time PCR (qPCR), have become in many cases the standard methods for the detection and identification of phytopathogenic bacteria (Palacio-Bielsa et al. 2009; Bull and Koike 2015; Loreti et al. 2018).

BIO-PCR (Schaad et al. 1995) consists of the biological amplification of the target organism followed by DNA amplification by PCR, which increases sensitivity when compared to conventional PCR (cPCR). However, the efficiency of this method depends on the specificity of the selective medium and primers. Some advantages associated with BIO-PCR are the elimination of PCR inhibitors and the detection of viable and culturable cells only. Its usefulness for detecting seed-borne pathogens has been demonstrated in a number of cases (Hassankiadeh et al. 2011; Kim et al. 2012; Singh et al. 2014).

Real-time PCR (qPCR) is a sensitive, robust and reproducible method for quantitative measurements (Schaad and Frederick 2002). qPCR has been widely used for the detection of phytopathogenic bacteria in various formats, including important Xanthomonas pathogens (Mavrodieva et al. 2004; Vandroemme et al. 2008; Palacio-Bielsa et al. 2011; Robène et al. 2015).
For the detection and identification of $\mathrm{Xcv}$, Trindade et al. (2007) developed a PCR-based method using primers Xcv1F/3R and/or RST2/Xcv3R, which amplify a partial sequence of the $h r p$ cluster ( $h r p B 6 / h r c N$ gene) that encodes the type III secretion system (TTSS), required for the pathogenicity of several plant pathogenic bacteria. These primers were tested with different sample types: (i) purified DNA, (ii) cell suspensions, (iii) macerated extracts from previously inoculated grapevine leaves, (iv) leaf or fruit washes followed by enrichment in liquid, or (v) solid culture medium. Detection of $\mathrm{Xcv}$, however, was not possible when plant tissue extracts were used directly in the reactions, but amplifications were positive when an enrichment step was used prior to PCR, so called BIO-PCR (Trindade et al. 2007).

Efficient control of bacterial plant diseases requires a combination of methods including the use of healthy plant material and cultivation practices (Janse and Wenneker 2002). In Brazil, grapevine cultivation and winemaking are in full expansion and are spreading to other regions with no viticulture tradition, such as the southeastern and midwestern regions. Thus, the use of healthy and tested material is essential to avoid the introduction and dissemination of bacterial canker in new areas. Given the need for early detection of Xcv in asymptomatic plant material, the present study aimed to develop new protocols for rapid, specific and sensitive detection of $\mathrm{Xcv}$, including its presence in latent form, applying both $\mathrm{cPCR}$ and $\mathrm{qPCR}$.

\section{Material and methods}

Bacterial strains

The bacterial strains used in the study are listed in Table 1 . Xcv strains were previously identified by PCR using the Xcv1F/3R primers (Trindade et al. 2007). All strains were preserved in sterile distilled water at room temperature and in 30\% glycerol at -20 ${ }^{\circ} \mathrm{C}$ and grown in semi-selective NYDAM (Peixoto et al. 2006) composed of $3 \mathrm{~g}$ of beef extract, $5 \mathrm{~g}$ of peptone, $10 \mathrm{~g}$ of glucose, $5 \mathrm{~g}$ of yeast extract, $18 \mathrm{~g}$ of agar, $0.1 \mathrm{~g}$ of ampicillin and distilled water to 1 liter, or in 523 medium (Kado and Heskett 1970) at $28^{\circ} \mathrm{C}$ for 2-3 days. In all PCR assays, DNA or cell suspension from Xcv strain UnB 1188 (SISGEN A99F2F2) was used as a positive control. For the detection assays of $\mathrm{Xcv}$ in 
Table 1 Bacterial strains used in this study

\begin{tabular}{|c|c|c|c|}
\hline Strains & Host & Origin* & Collection year \\
\hline \multicolumn{4}{|l|}{ Xanthomonas citri pv. viticola } \\
\hline NCPPB 2475 (LMG 965) & Vitis vinifera & India & 1972 \\
\hline $\mathrm{A} 2, \mathrm{~A} 3, \mathrm{~A} 11, \mathrm{~A} 12$ & Vitis vinifera & Petrolina - PE & 2010 \\
\hline AR1, AR2 & Vitis vinifera & Petrolina - PE & 2012 \\
\hline $\mathrm{AM} 1, \mathrm{AM} 2, \mathrm{AM} 3$ & Amaranthus sp. & Petrolina - PE & 2012 \\
\hline P1S5, P1S6 (CFBP 7764), P1S9, P1S16, & Vitis vinifera & Petrolina - PE & 2012 \\
\hline $\mathrm{P} 2 \mathrm{~S} 1, \mathrm{P} 2 \mathrm{~S} 2, \mathrm{P} 2 \mathrm{~S} 4, \mathrm{P} 2 \mathrm{~S} 6$ & Vitis vinifera & Petrolina - PE & 2012 \\
\hline RS 2, RS 8, RS 10, RS 11 & Vitis vinifera & Curaçá, BA & 2012 \\
\hline TR 1 , TR 3 & Vitis vinifera & Petrolina - PE & 2012 \\
\hline $\begin{array}{l}\text { UnB 1183, UnB 1184, UnB 1188, UnB 1189, UnB } 1190 \text {, } \\
\text { UnB 1192, UnB 1193, UnB } 1194\end{array}$ & Vitis vinifera & Petrolina - PE & 1998 \\
\hline UnB 1205 & Vitis vinifera & Sobradinho - BA & 2000 \\
\hline UnB 1307, UnB 1309, UnB 1313, UnB 1315 & Vitis vinifera & Petrolina - PE & 2005 \\
\hline UnB 1318 & Vitis vinifera & $\mathrm{na}^{* *}$ & 2006 \\
\hline UnB 1429 & Vitis vinifera & Petrolina - PE & 2016 \\
\hline $\mathrm{Xcv} 2$ & Vitis vinifera & Lagoa Grande - PE & 2008 \\
\hline Agrobacterium tumefaciens UnB 1138 & Daucus carota & na & 1996 \\
\hline Acidovorax citrulli UnB 1232 & Cucumis melo & Petrolina - PE & 2000 \\
\hline Burkholderia cepacia UnB 1134 & Allium sativum & na & 1996 \\
\hline Clavibacter michiganensis subsp. michiganensis UnB 1391 & Solanum lycopersicum & Monte Alto - MG & 2014 \\
\hline Curtobacterium flaccumfaciens pv. flaccumfaciens UnB 1376 & Phaseolus vulgaris & Alto Paraíso - GO & 2013 \\
\hline Dickeya chrysanthemi UnB 336 & Beta vulgaris var. cicla & na & 1983 \\
\hline Erwinia psidii IBSBF 435 & Psidium guajava & Valinhos - SP & 1982 \\
\hline Pectobacterium carotovorum subsp. carotovorum UnB 1036 & Solanum lycopersicum & Planaltina - DF & 1992 \\
\hline Pseudomonas cichorii UnB 1387 & Gerbera sp. & Brazlândia - DF & 2013 \\
\hline Pseudomonas corrugata UnB 1142 & Solanum lycopersicum & na & 1996 \\
\hline Pseudomonas syringae pv. tomato UnB 853 & Solanum lycopersicum & Vargem Bonita - DF & 1991 \\
\hline Ralstonia solanacearum UnB 1173 & Solanum lycopersicum & Planaltina - DF & 1998 \\
\hline Xanthomonas axonopodis pv. manihotis UnB 1111 & Manihot esculenta & Paranavaí - PR & 1996 \\
\hline Xanthomonas axonopodis pv. passiflorae UnB 1395 & Passiflora edulis & Vargem Bonita - DF & 2016 \\
\hline Xanthomonas axonopodis pv. phaseoli UnB 187 & Phaseolus vulgaris & Brasília - DF & 1981 \\
\hline Xanthomonas axonopodis pv. ricini UnB 607 & Ricinus communis & Ibiapina - CE & 1985 \\
\hline Xanthomonas campestris pv. campestris UnB 1394 & Brassica oleracea & Vargem Bonita - DF & 2016 \\
\hline Xanthomonas campestris pv. vitians UnB 845 & Lactuca sativa & Vargem Bonita - DF & 1991 \\
\hline Xanthomonas citri pv. citri UnB 92 & Citrus sp. & na & na \\
\hline Xanthomonas citri pv. fuscans UnB 773 & Phaseolus vulgaris & na & 1990 \\
\hline Xanthomonas citri pv. malvacearum UnB 87 & Gossypium sp. & Planaltina - DF & 1980 \\
\hline Xanthomonas citri pv. mangiferaeindicae UnB 764 & Mangifera indica & Planaltina - DF & 1990 \\
\hline Xanthomonas cucurbitae UnB 1080 & Cucumis sativus & Vargem Bonita- DF & 1995 \\
\hline \multicolumn{4}{|l|}{ Bacteria associated to grapevine (non-xanthomonads) } \\
\hline 2 strains & Vitis vinifera & Brasília - DF & 2016 \\
\hline 29 strains & Vitis vinifera & Petrolina - PE & 2016 \\
\hline 10 strains & Vitis spp. & Petrolina - PE & 2016 \\
\hline
\end{tabular}

\footnotetext{
* PE, state of Pernambuco; BA, Bahia; MG, Minas Gerais; GO, Goiás; SP, São Paulo; DF, Federal District; PR, Paraná.

** information not available
} 
grapevine, healthy detached leaves of 'Thompson Seedless' plants, kept in a greenhouse, were used.

DNA extraction and templates for PCR

PCR templates used in the detection assays were: (i) bacterial total genomic DNA, (ii) bacterial cell suspension, (iii) DNA from grapevine leaves, and (iv) DNA purified from grapevine leaf extract spiked with bacterial suspension. The concentration of the Xcv cell suspensions was determined by spectrophotometry (A550 $=0.575$, using a digital spectrophotometer UV-1203 [Shimadzu Corporation, Japan]) corresponding to $10^{8}$ $\mathrm{CFU} \mathrm{m}{ }^{-1}$ and confirmed by colony counting after $48 \mathrm{~h}$ growth at $28^{\circ} \mathrm{C}$ on the semi-selective NYDAM medium. Genomic DNA was extracted from 48h-cultures, using the PureLink extraction kit (Invitrogen), according to the manufacturer's recommendations. The CTAB method was used for extracting DNA from grapevine leaves (Doyle and Doyle 1990). Purification of DNA from grapevine leaf extracts spiked with bacterial suspension was performed according to the protocol described by Llop et al. (1999). DNA integrity and purity were verified by $1 \%$ agarose gel electrophoresis and by the NanoVue spectrophotometer (GE Healthcare - Life Sciences). DNA was diluted to $10 \mathrm{ng} \mathrm{\mu l}^{-1}$ and stored at $20{ }^{\circ} \mathrm{C}$ until used.

\section{Primer design}

New primers were designed based on the partial sequences of the hrpB6 ( $h r c N)$ gene (Xcv primers) (Trindade et al. 2007) and the xanthomonadin biosynthetic pathway genes (Xpig primers) (Table S1). The lack of colony pigmentation in Xcv, different from most Xanthomonas spp., can be used as a phenotypic marker, and to genotypically differentiate Xcv from other yellow and white Xanthomonas species. For that, sequences of the xanthomonadin biosynthetic gene cluster from Xcv (CBZT010000000) and Xanthomonas citri pv. mangiferaeindicae (KF991092), were downloaded from GenBank and aligned using the MAFFT plugin (Katoh et al. 2002) in Geneious R8 (Kearse et al. 2012). The region selected for primer design was between an intergenic zone and the 3-oxoacyl-[acyl-carrier-protein] reductase, absent in Xanthomonas citri pv. mangiferaeindicae due to the presence of a transposon (Fig. S1). Furthermore, the reverse primer (Xpig 1R) was designed inside a polymorphic region in which
Xanthomonas citri pv. citri differs from the pathotype strain of Xcv (LMG 965) as described by Midha and Patil (2014). Primers were designed with the Primer3 plugin (Rozen and Skaletsky 2000) also in Geneious R8 and checked for \%GC, hairpin, self-dimer and pair dimer. The designed primers were tested in silico against the entire genome sequence of Xcv and Xanthomonas citri pv. mangiferaeindicae. Primers were synthesized by Invitrogen ${ }^{\circledR}$ (Life Technologies).

\section{Conventional PCR (cPCR)}

The primers designed for Xcv detection were initially tested in cPCR. Cell suspensions $\left(10^{7} \mathrm{CFU} \mathrm{ml^{-1 }}\right)$ from seven Xcv strains were used. The negative control consisted of sterilized distilled water. The assays were repeated twice with three replicates per sample. Primers were selected following these criteria: amplification of the product of expected size, absence of nonspecific bands, reproducibility and positive amplification for all Xcv strains tested. The reactions were carried out in a thermal cycler (My Cycler, Bio-Rad) programmed to $2 \mathrm{~min}$ at $95^{\circ} \mathrm{C}$, followed by 30 cycles of $30 \mathrm{~s}$ at $95^{\circ} \mathrm{C}$, $30 \mathrm{~s}$ at $64^{\circ} \mathrm{C}$ (Xcv primers) or $68^{\circ} \mathrm{C}$ (Xpig primers), and $15 \mathrm{~s}$ at $72^{\circ} \mathrm{C}$, followed by a final extension of $10 \mathrm{~min}$ at $72{ }^{\circ} \mathrm{C}$. Reactions contained: $0.1 \mathrm{mM}$ of each dNTP, $1.5 \mathrm{mM} \mathrm{MgCl}_{2}, 0.5 \mu \mathrm{M}$ (Xcv primers) or $0.2 \mu \mathrm{M}$ (Xpig primers) of each primer, $1 \mathrm{X}$ PCR buffer (20 mM Tris $\mathrm{HCl} \mathrm{pH} 8.4,50 \mathrm{mM} \mathrm{KCl}$ ), $1 \mathrm{U}$ of Taq polymerase (Invitrogen), $2 \mu$ of DNA template, and sterile distilled water to a final volume of $12 \mu \mathrm{l}$. PCR products were analyzed by agarose $(1.5 \%)$ gel electrophoresis in $0.5 \mathrm{X}$ TBE buffer $(50 \mathrm{mM}$ Tris, $1 \mathrm{mM}$ $\mathrm{Na}_{2}$ EDTA, $50 \mathrm{mM}$ boric acid [pH 8.3]), stained with ethidium bromide $\left(0.5 \mu \mathrm{g} \mathrm{ml}^{-1}\right)$ and registered using the digital system L-PIX ST ${ }^{\circledR}$ (Loccus Biotechnology).

\section{Real time PCR (qPCR)}

The primer pairs selected in cPCR were tested in qPCR. The criteria for choosing the best combination were: reaction efficiency $(100 \pm 10 \%)$, sensitivity and absence of dimers and nonspecific products. Efficiency and sensitivity in real-time PCR were evaluated by generating standard curves by serial dilutions (1:10) of Xcv geno-

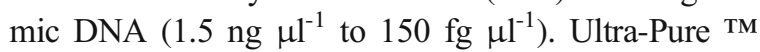
DNase/RNase-Free (Invitrogen) distilled water was included as negative control. The assays were repeated twice and for each dilution eight replicates were 
performed. The reactions were performed in a StepOnePlus ${ }^{\mathrm{TM}}$ Real-Time PCR System (Applied Biosystems) thermocycler using the SYBR ${ }^{\circledR}$ Green system for fluorescence detection. Amplification reactions were prepared to a final volume of $15 \mu \mathrm{l}$ containing $1 \mu \mathrm{l}$ of DNA template, 1X Master Mix SYBR Green (Applied Biosystems) and $0.05 \mu \mathrm{M}$ (Xcv primers) or $0.04 \mu \mathrm{M}$ (Xpig primers). The cycling conditions were: $10 \mathrm{~min}$ at $95^{\circ} \mathrm{C}$, followed by 40 cycles of $15 \mathrm{~s}$ at $95^{\circ} \mathrm{C}$, $1 \mathrm{~min}$ at $64{ }^{\circ} \mathrm{C}$ (Xcv primers) or $67^{\circ} \mathrm{C}$ (Xpig primers) and a final extension of $1 \mathrm{~min}$ at $60{ }^{\circ} \mathrm{C}$. To verify the absence of primer dimers or nonspecific products, a melting curve was generated for all reactions.

Primer specificity and sensitivity

Cell suspensions $\left(10^{7} \mathrm{CFU} \mathrm{ml}^{-1}\right)$ from 40 strains of $\mathrm{Xcv}$, 11 strains belonging to different Xanthomonas species, 12 strains of other phytopathogenic bacteria, and 41 strains of epiphytic/endophytic bacteria associated with nine grape varieties (Table 1) were used to confirm primer specificity. To obtain bacteria associated with grapevine tissue, leaf fragments were macerated with a few droplets of water, followed by plating in 523 medium. Pure cultures of these strains were established and characterized phenotypically, according to standard protocols (Schaad et al. 2001). Purified DNA from grapevine leaves was also tested to prevent false positives.

The sensitivity of detection of Xcv by cPCR was determined using genomic DNA and bacterial cell suspensions. Serial dilutions $(1: 10)$ were performed to obtain concentrations ranging from $1.5 \mathrm{ng}^{-1} \mathrm{l}^{-1}$ to $150 \mathrm{fg}$ $\mu \mathrm{l}^{-1}$ for genomic DNA and $10^{8} \mathrm{CFU} \mathrm{ml}^{-1}$ to $1 \mathrm{CFU} \mathrm{ml}{ }^{-1}$ for bacterial suspensions. The assays were repeated twice, and for each dilution three reactions were performed. Negative and positive controls were sterile distilled water and purified genomic DNA from $\mathrm{Xcv}$ strain UnB 1188, respectively.

The efficiency and sensitivity of detection of Xcv by qPCR were determined by generating standard curves by


$\left.150 \mathrm{fg}^{-1} \mathrm{l}^{-1}\right)$ and bacterial suspensions $\left(10^{8}\right.$ to $1 \mathrm{CFU}$ $\mathrm{ml}^{-1}$ ). The slope of the generated standard curve was used to estimate the efficiency of the reaction. Negative and positive controls were Ultra-Pure TM DNase/RNase-Free water (Invitrogen) and genomic DNA purified from Xcv strain UnB 1188, respectively. The assays were repeated twice with eight replicates for each dilution.
Detection limit of Xcv in plant tissue by total DNA extraction and PCR

To determine the detection limit of Xcv in plant material, we used total DNA extraction of grapevine leaf extracts spiked with bacterial suspensions at different concentrations. To prepare the extract, $1 \mathrm{~g}$ (fresh weight) of leaf tissue was macerated with $15 \mathrm{ml}$ of sterilized distilled water. One hundred microliters of suspensions at concentrations from $10^{8}$ to $10^{1} \mathrm{CFU} \mathrm{ml}^{-1}$ were added to $900 \mu \mathrm{l}$ of leaf extract. Thus, each sample contained decreasing amounts of cells, ranging from $10^{7}$ to $1 \mathrm{CFU}$ $\mathrm{ml}^{-1}$. Bacterial suspensions at the same concentrations were tested as positive controls and the negative control consisted of healthy leaf extracts. DNA of the extracts was purified and used in CPCR and qPCR, as previously described. The assay was repeated twice, with four independent replicates for each inoculum concentration and two amplification reactions each, in total eight reactions per treatment. As positive and negative PCR controls, Xcv purified genomic DNA and sterilized distilled water were used.

Detection limit of Xcv in plant tissue after an enrichment step (BIO-PCR)

To determine the detection limit of Xcv in plant material employing an enrichment step, leaf extracts spiked with bacterial suspensions were prepared as described above. For each sample, $100 \mu \mathrm{l}$ of the extract were streaked onto one NYDAM plate. Plates were incubated at $28^{\circ} \mathrm{C}$ for $72 \mathrm{~h}$. The same volume of bacterial suspensions $\left(10^{8}\right.$ to $10^{1} \mathrm{CFU} \mathrm{ml}{ }^{-1}$ ) was plated as positive controls, and the negative control consisted of healthy leaf extracts. After $72 \mathrm{~h}$, each plate was washed with $1 \mathrm{ml}$ of sterile distilled water, and the resulting cell suspension was diluted 1:100 and used as templates for both cPCR and qPCR. The assay was repeated twice, each one with three replicates (plates) for each bacterial concentration and three amplification reactions for each replicate, in total nine reactions per treatment (bacterial concentration). Positive and negative PCR controls were used as described in the previous assay.

qPCR and cPCR for Xcv detection in bacterial canker-infected grapevines

Leaves, stems, or petioles of 17 grapevine varieties and leaves of Amaranthus sp. were collected in Petrolina, 





Fig. 1 Specificity of primer pairs (a) Xcv18F/19R and (b) Xpig2F/ $1 \mathrm{R}$ for detection and identification of Xanthomonas citri pv. viticola. Lanes 1: NCPPB 2475; 2: UnB 1188; 3: UnB 1205; 4: UnB 92; 5 : UnB 764; 6: UnB 773; 7: UnB 607; 8: UnB 1395; 9: UnB 187; 10-11: endophytic/ epiphytic bacteria from grape leaves; 12 : DNA from grapevine; 13: PCR water control; M: 100-bp ladder (Ludwig $^{\circledR}$ ) Lanes 1-3:

Xanthomonas citri pv. viticola; 4 : $X$. citri pv. citri; $5: X$. citri pv. mangiferaindicae; 6 . X. citri pv. fuscans; 7: $X$. axonopodis pv. ricini; $8: X$. axonopodis pv. passiflorae; 9: X. axonopodis pv. phaseoli
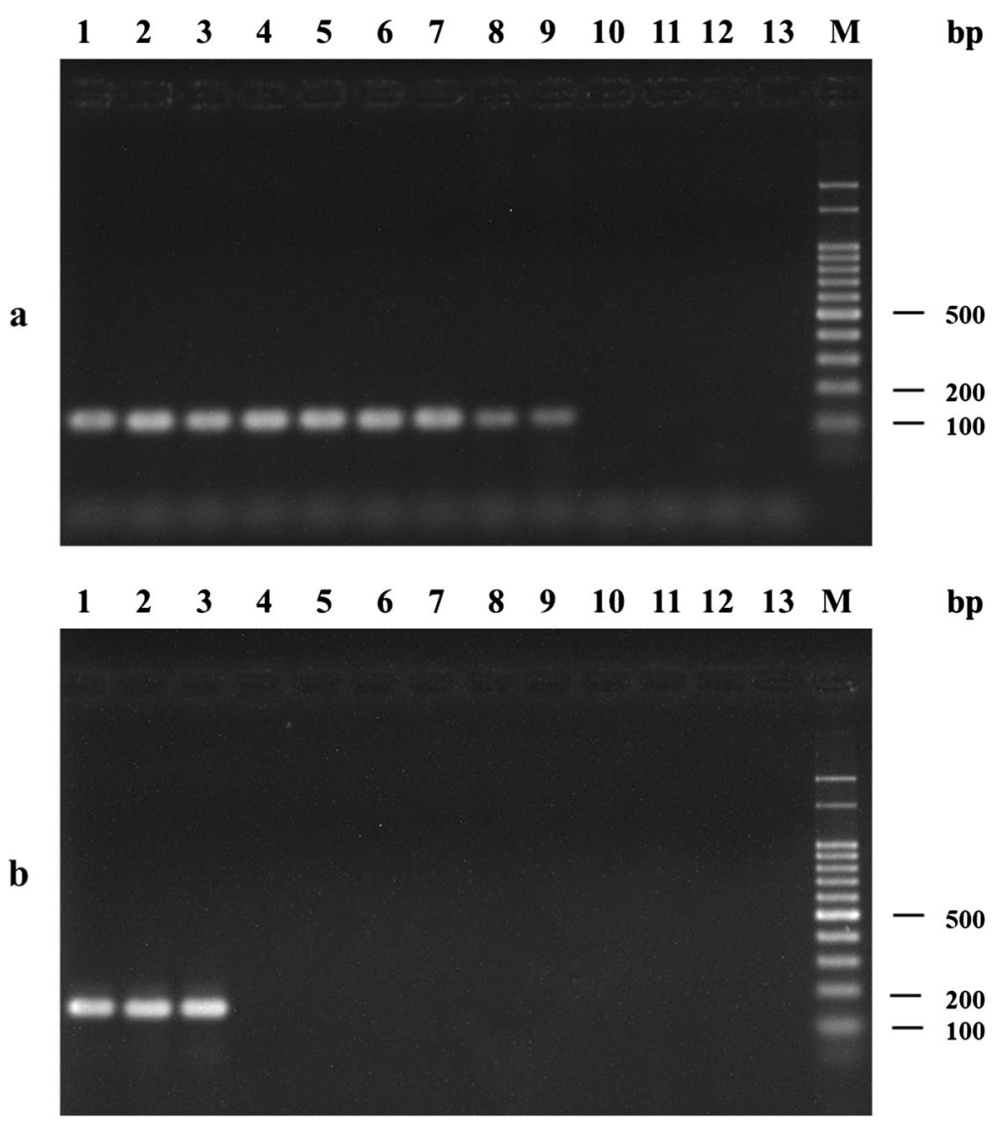

state of Pernambuco, Brazil, in a table grape vineyard showing high incidence of bacterial canker. Seventyfive leaf samples were collected, 25 showing typical bacterial canker symptoms and 50 symptomless. In addition, 12 samples were collected from roots of Red Globe plants showing severe canker symptoms. Samples from different hybrids, one rootstock variety (IAC 313), and cv. Red Globe plants growing in a greenhouse were also tested. They were originated from a commercial nursery and were naturally infected. A total of 25 leaf/petiole samples were collected, 11 with symptoms and 14 with no visible symptoms. All samples were washed under tap water, dried on paper towels, and an extract was obtained after maceration (1 g) in $15 \mathrm{ml}$ of sterile distilled water followed by plating $(100 \mu \mathrm{l})$ onto NYDAM medium. Plates were incubated at $28{ }^{\circ} \mathrm{C}$ for $36 \mathrm{~h}$ (symptomatic samples) or $72 \mathrm{~h}$ (symptomless samples). After washing and dilution (1:100), aliquots from the plate washes were used for $\mathrm{cPCR}$ with primers Xpig2F/1R and qPCR with Xcv18F/19R. Each sample was analyzed in triplicates, and positive and negative controls were added as previously described.

\section{Results}

Primer design and selection

In silico searches of the new primer and amplicon sequences revealed no significant homology with the sequences available in the Genbank database. Based on previously established criteria for CPCR, six out of 10 pairs of primers targeting the $h r p B$ gene (Xcv primers), and the two pairs targeting the xanthomonadin coding cluster (Xpig primers) were selected (Table S1). All selected primers were tested in qPCR. Based on the screening via qPCR, the pair Xcv18F/19R showed the best results. The reactions showed high efficiency, and the melting curves showed a single peak indicating the amplicon's melting temperature $(\mathrm{Tm})$, without interfering signals, indicating the amplification only of the desired amplicon. The Xpig primers showed low efficiency in qPCR, probably because of the longer amplicon (above $150 \mathrm{bp}$ ) compared to Xcv18F/19R (Table S1). 

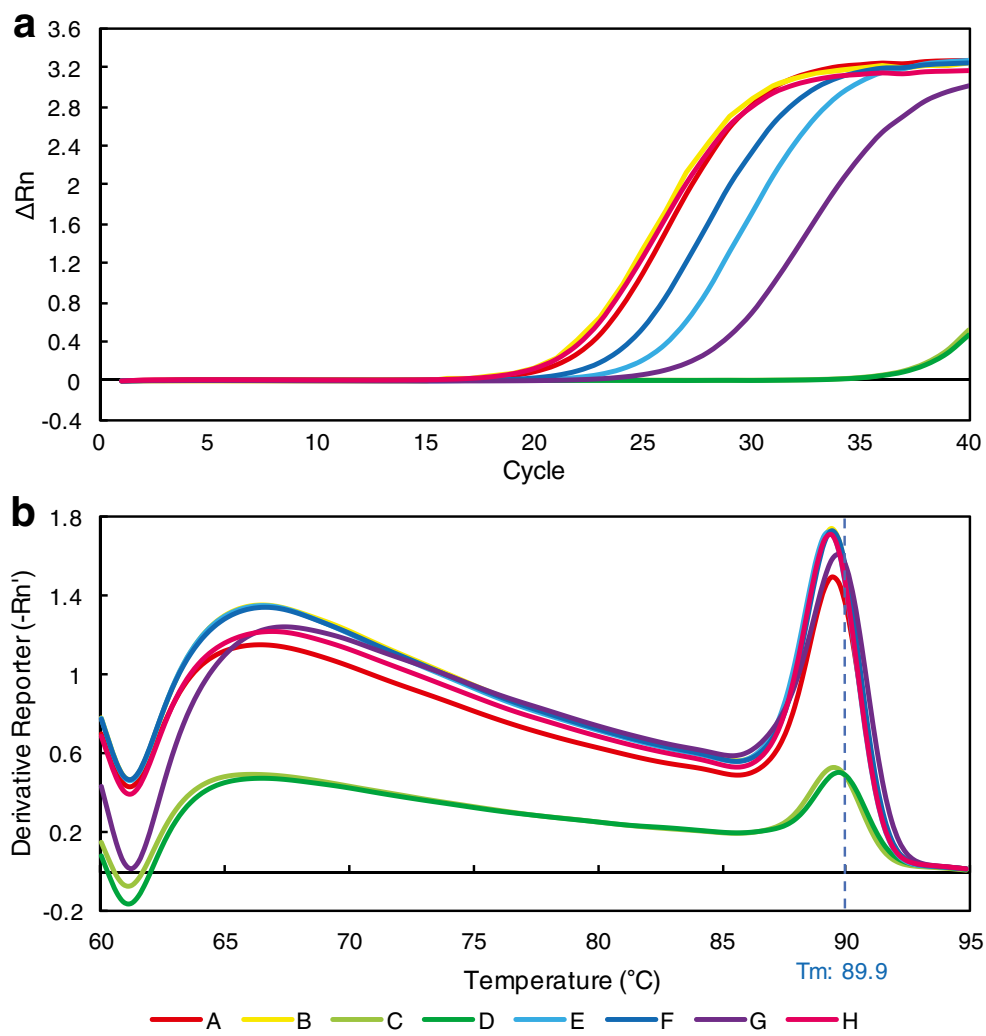

Fig. 2 Amplification (a) and melting (b) curves of real-time PCR

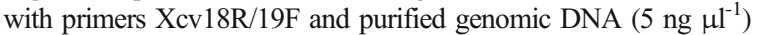
from different species of Xanthomonas. Color legend: A - X. citri pv. viticola (UnB 1188); B - X. citri pv. viticola (NCPPB 2475); C -

Primer specificity

Specificity tests performed with cPCR showed that all selected primers amplified DNA from all 40 strains of $\mathrm{Xcv}$, but not from healthy, non-contaminated grape leaves or from 41 strains of epiphytic/endophytic bacteria associated with those leaves. Xpig primers were highly specific for Xcv, since the amplification was negative with all tested strains of other phytopathogenic bacteria. However, reactions using the primers for the $h r p B$ gene (Xcv primers) showed positive amplifications for some Xanthomonas strains (Table 2, Fig. 1). The six Xanthomonas strains ( $X$. axonopodis pv. passiflorae, $X$. citri pv. citri, X. citri pv. fuscans, $X$. citri pv. mangiferaeindicae, $X$. axonopodis $\mathrm{pv}$. phaseoli and $X$. axonopodis pv. ricini) with positive amplification using primers Xcv18F/19R, were also tested in qPCR, to verify any differences in $\mathrm{Ct}$ (cycle thresholds) and $\mathrm{Tm}$ in relation to Xcv. It was observed that the amplicons from these species all had very close $\mathrm{Ct}$ and $\mathrm{Tm}$ values. The exceptions were $X$. axonopodis
$X$. axonopodis pv. passiflorae (UnB 1395); D - X. axonopodis pv. phaseoli (UnB 187). E - X. axonopodis pv. ricini (UnB 607); F - X. citri pv. magiferaindicae (UnB 764); G - X. citri pv. fuscans (UnB 773); H - X. citri pv. citri (UnB 92)

pv. passiflorae $(\mathrm{Ct}=35.09)$ and $X$. axonopodis $\mathrm{pv}$. phaseoli $(\mathrm{Ct}=36.06)$, which showed significantly higher $\mathrm{Cts}$ at the same DNA concentration $\left(5 \mathrm{ng} \mathrm{\mu l}^{-1}\right)$ of $\mathrm{Xcv}(\mathrm{Ct}=18.40)$ (Fig. 2).

cPCR and qPCR: sensitivity

The sensitivity of $\mathrm{Xcv}$ detection by $\mathrm{cPCR}$ was assessed using the Xcv18F/19R and Xpig2F/1R primer pairs. The Xcv18F/19R pair was chosen because of its efficiency for both cPCR and qPCR (Table 3) and the Xpig2F/1R pair because of its high specificity for Xcv. The sensitivity with cPCR was the same for both

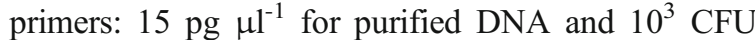
$\mathrm{ml}^{-1}$ for bacterial suspension (Table 4). Sensitivity of qPCR with Xcv18F/19R primers was higher and the detection limits were $1.5 \mathrm{pg}^{-1} \mathrm{l}^{-1}$ for genomic DNA and $10^{2} \mathrm{CFU} \mathrm{ml^{-1 }}$ for cell suspension (Table 4). The regression and amplification curves obtained by plotting $\mathrm{Ct}$ values versus values of the initial amount of template in the reaction are shown in Fig. 3 and S2. 
Detection limit of Xcv in plant tissue

The detection limit of Xcv in leaf extracts spiked with bacterial suspensions was evaluated by two methods, simple DNA extraction or extract enrichment in NYDAM medium (BIO-PCR), followed by cPCR with both sets of primers, and qPCR with the Xcv primers (18F/19R) only. The detection limit by the simple DNA extraction method was $10^{3} \mathrm{CFU} \mathrm{ml}^{-1}$ in cPCR, with no difference between the primers used. In qPCR, the limit was $10^{2} \mathrm{CFU} \mathrm{ml}{ }^{-1}$ with an average $\mathrm{Ct}$ of 35.83 (Table 5). Using BIO-PCR the detection limit in cPCR was from an initial concentration of $10^{2} \mathrm{CFU} \mathrm{ml}{ }^{-1}$, with no difference between the primers used. However, using the real-time format, the detection limit decreased 10-fold, with an initial concentration of only $10^{1} \mathrm{CFU} \mathrm{ml}^{-1}(\mathrm{Ct}=34.42)$ (Table 5). Therefore, the combination of bacterial
Table 3 Efficiency of real-time PCR (qPCR) with primer pair Xcv18F/19R, evaluated from calibration curves obtained with ge-

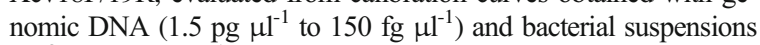
$\left(10^{8}\right.$ to $\left.1 \mathrm{CFU} \mathrm{ml}{ }^{-1}\right)$ of Xanthomonas citri pv. viticola (Xcv)

\begin{tabular}{lcccc}
\hline Template & ${ }^{\mathrm{a}} \mathrm{E}(\%)$ & ${ }^{\mathrm{b}} \mathrm{R}^{2}$ & ${ }^{\mathrm{c}}$ Slope & ${ }^{\mathrm{d}} \mathrm{Y}=$ int \\
\hline gDNA Xcv & 99.16 & 0.996 & 3.342 & 25.827 \\
gDNA Xcv & 94.98 & 0.990 & 3.448 & 26.678 \\
Cell suspension Xcv & 92.87 & 0.995 & 3.506 & 44.310 \\
Cell suspension Xcv & 92.54 & 0.994 & 3.515 & 44.428 \\
\hline
\end{tabular}

${ }^{\mathrm{a}} \mathrm{E}=$ PCR efficiency, $100 \%$ is the maximum theoretical value, which means perfect doubling of molecules at each cycle.

${ }^{\mathrm{b}} \mathrm{R}^{2}$ is a measure of data linearity among technical replicates of the same and different serial dilutions; 1 is the best fit.

${ }^{\mathrm{c}}$ The slope is the angular coefficient (a) of the equation for the standard curve $(y=a x+b)$.

${ }^{\mathrm{d}} \mathrm{Y}=$ int represents the value of $\mathrm{Ct}$ where the curve crosses the $y$-axis.

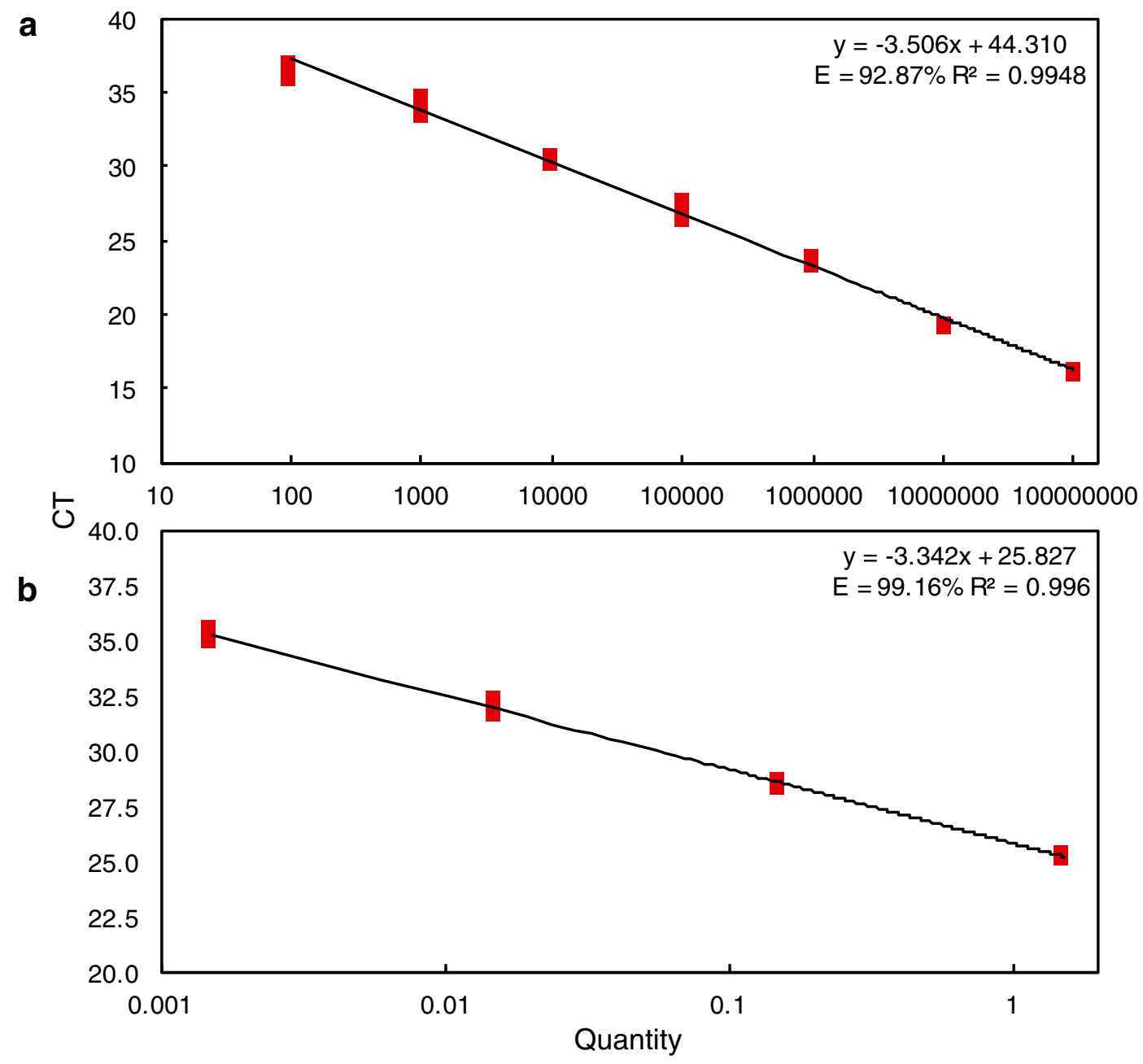

Fig. 3 Real-time PCR (SYBR ${ }^{\circledR}$ Green) standard curves with primers Xcv18F/19R for detection of (a) genomic DNA ( $1.5 \mathrm{ng} \mu \mathrm{l}^{-1}$ to 150 fg $\left.\mu \mathrm{l}^{-1}\right)$ and (b) cell suspension $\left(10^{8}\right.$ to $1 \mathrm{CFU} \mathrm{ml^{-1 }}$ ) from Xanthomonas citri pv. viticola 
Table 4 Sensitivity of conventional PCR (cPCR) and real-time PCR (qPCR) for detecting genomic DNA or cell suspensions of Xanthomonas citri pv. viticola. For qPCR, Ct values are indicated (the numbers presented are the means of two independent experiments)

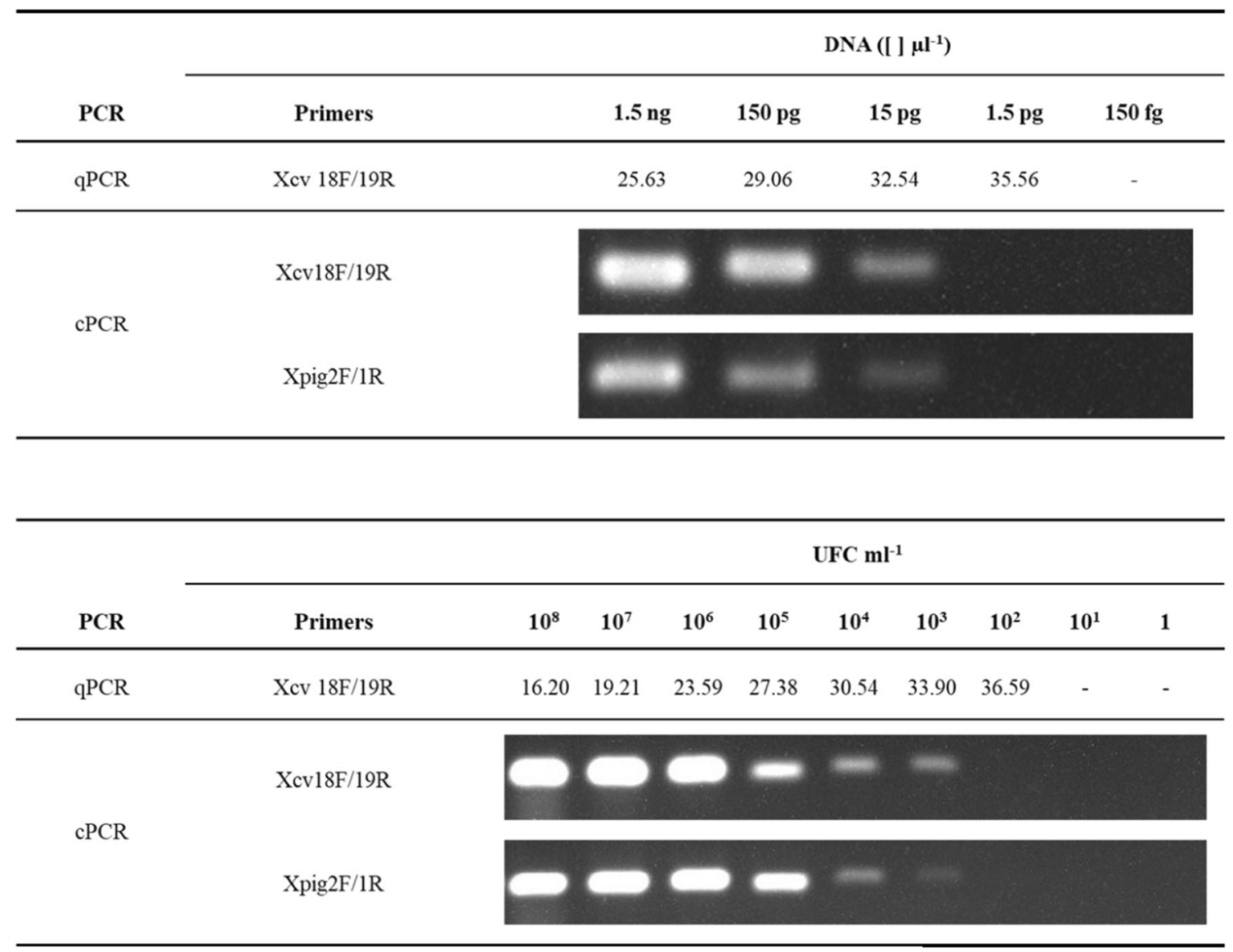

enrichment in culture media with qPCR would allow the highest sensitivity for pathogen detection. In that case, cycle threshold values $\leq 34.42$ were considered as the cut-off for a true positive result.

qPCR and cPCR for Xcv detection in a bacterial canker-infected area

Because of its higher sensitivity, the method that employed enrichment in culture medium was chosen for protocol validation in an area with natural occurrence of bacterial canker. In all 75 field samples ( 25 with symptoms and 50 with no visible symptoms), Xcv was detected by both cPCR and qPCR. For the 12 root samples, without visible symptoms, $75.0 \%$ were positive by qPCR $(\mathrm{Ct}=28.10)$ and $50.0 \%$ by cPCR. From the total of 25 samples collected in the greenhouse, Xcv was detected in $100 \%$ of symptomatic and $85.7 \%$ (12/ 14) of asymptomatic samples. Xcv was not detected in the rootstock IAC 313 and in one of the hybrid accessions (Tables 6 and 7). Bacterial isolation on NYDAM was successful for all symptomatic samples confirming the results obtained by cPCR and qPCR.

\section{Discussion}

Grapevine bacterial canker (GBC) caused by X. citri pv. viticola is responsible for losses in Brazil and India, affecting mostly table grape production. The emergence of Xcv in northeastern Brazil in 1998 and later in other parts of the country is probably due to pathogen introduction and dispersion by propagative plant material. In São Paulo state, for example, Xcv detection in 2009 caused the eradication of approximately 4,700 plants in a table grape vineyard (Rodrigues Neto et al. 2011). Consequently, exclusion of Xcv-infected material is very important for preventing and managing GBC. For this 
Table 5 Sensitivity of conventional PCR (cPCR) and real-time PCR (qPCR) for detecting Xanthomonas citri pv. viticola on leaf extracts spiked with bacterial cell suspensions. after total DNA extraction (top) or enrichment for $72 \mathrm{~h}$ on semi-selective medium (bottom). For qPCR, Ct values are indicated (the numbers presented are the means of two independent experiments)

\begin{tabular}{|c|c|c|c|c|c|c|c|c|c|}
\hline \multirow[b]{2}{*}{ PCR } & \multirow[b]{2}{*}{ Primers } & \multicolumn{8}{|c|}{ UFC ml-1 } \\
\hline & & $10^{7}$ & $10^{6}$ & $10^{5}$ & $10^{4}$ & $10^{3}$ & $10^{2}$ & $10^{1}$ & 1 \\
\hline $\mathrm{qPCR}$ & $\mathrm{Xcv} 18 \mathrm{~F} / 19 \mathrm{R}$ & 19.45 & 22.46 & 25.86 & 29.55 & 32.96 & 35.83 & - & - \\
\hline \multicolumn{10}{|c|}{$\mathrm{Xcv} 18 \mathrm{~F} / 19 \mathrm{R}$} \\
\hline & $\mathrm{Xpig} 2 \mathrm{~F} / \mathrm{R}$ & & & & & & & & \\
\hline qPCR & Xcv $18 F / 19 R$ & 17.00 & 17.70 & 20.12 & 20.42 & 21.14 & 22.64 & 34.42 & - \\
\hline & Xcv18F/19R & & & & & & & & \\
\hline \multicolumn{10}{|l|}{ cPCR } \\
\hline & Xpig2F/1R & & & & & & & & \\
\hline
\end{tabular}

purpose, the development of effective detection methods that combine high specificity and sensitivity is required.
A PCR-based method for detection of Xcv in symptomatic and asymptomatic plants was already developed

Table 6 PCR detection of Xanthomonas citri pv. viticola in symptomatic grapevine and Amaranthus sp. leaves in a bacterial canker-infected area in Brazil

\begin{tabular}{llll}
\hline Grapevine variety/ other hosts & Site & qPCR*(Ct**) & cPCR*** \\
\hline Benitaka & Field & $1 / 1(20.39)$ & $1 / 1$ \\
BRS Isis & Field & $1 / 1(18.75)$ & $1 / 1$ \\
BRS Linda & Field & $5 / 5(21.22)$ & $5 / 5$ \\
BRS Núbia & Field & $2 / 2(18.98)$ & $2 / 2$ \\
BRS Vitória & Field & $2 / 2(19.74)$ & $2 / 2$ \\
Crimson & Field & $2 / 2(19.41)$ & $2 / 2$ \\
Italia & Field & $1 / 1(19.20)$ & $1 / 1$ \\
Niagara Rosada & Field & $1 / 1(18.87)$ & $1 / 1$ \\
Red Globe & Field & $6 / 6(20.32)$ & $6 / 6$ \\
Sugraone & Field & $1 / 1(20.94)$ & $1 / 1$ \\
Thompson Seedless & Field & $3 / 3(22.10)$ & $3 / 3$ \\
Vitis spp hybrids & greenhouse & $10 / 10(22.57)$ & $10 / 10$ \\
Red Globe & greenhouse & $1 / 1(19.70)$ & $1 / 1$ \\
Total & & $\mathbf{3 6 / 3 6}$ & $\mathbf{3 6 / 3 6}$ \\
\hline
\end{tabular}

* number of positive samples by real-time PCR/ total number of tested samples

** Ct (cycle threshold): means of three replicates for each positive sample

*** number of positive samples by conventional PCR/ total number of tested samples 
Table 7 PCR detection of Xanthomonas citri pv. viticola in asymptomatic grapevines and Amaranthus sp. in a bacterial canker-infected area in Brazil

\begin{tabular}{|c|c|c|c|c|}
\hline Grapevine variety/ other hosts & Site & Sample & $\mathbf{q P C R} *(\mathbf{C t} * *)$ & $\mathbf{c P C R}^{* * *}$ \\
\hline Benitaka & Field & Leaf & $2 / 2(27.84)$ & $2 / 2$ \\
\hline Brasil & Field & Leaf & $2 / 2(26.05)$ & $2 / 2$ \\
\hline BRS Cora & Field & Leaf & $4 / 4(22.60)$ & $4 / 4$ \\
\hline BRS Isis & Field & Leaf & 4/4 (23.19) & $4 / 4$ \\
\hline BRS Linda & Field & Leaf & $2 / 2(24.81)$ & $2 / 2$ \\
\hline BRS Magna & Field & Leaf & $7 / 7(22.47)$ & $7 / 7$ \\
\hline BRS Núbia & Field & Leaf & $2 / 2(22.16)$ & $2 / 2$ \\
\hline BRS Vitória & Field & Leaf & $1 / 1(25.70)$ & $1 / 1$ \\
\hline Crimson & Field & Leaf & $1 / 1(17.51)$ & $1 / 1$ \\
\hline IAC 572 & Field & Leaf & $2 / 2(22.50)$ & $2 / 2$ \\
\hline Isabel & Field & Leaf & $5 / 5(28.52)$ & $5 / 5$ \\
\hline Isabel Muscat & Field & Leaf & $3 / 3(23.32)$ & $3 / 3$ \\
\hline Italia & Field & Leaf & $2 / 2(26.38)$ & $2 / 2$ \\
\hline Niagara Rosada & Field & Leaf & $4 / 4(26.14)$ & $4 / 4$ \\
\hline Red Globe & Field & Leaf & $1 / 1(19.83)$ & $1 / 1$ \\
\hline Sugraone & Field & Leaf & $3 / 3(20.26)$ & $3 / 3$ \\
\hline Thompson Seedless & Field & Leaf & $3 / 3(24.09)$ & $3 / 3$ \\
\hline Red Globe & Field & Roots & 9/12 (28.10) & $6 / 12$ \\
\hline Amaranthus sp. & Field & Leaf & $2 / 2(26.54)$ & $2 / 2$ \\
\hline Vitis spp hybrids & greenhouse & Leaf & $12 / 13(21.16)$ & $12 / 13$ \\
\hline IAC 313 & greenhouse & Leaf & $0 / 1(\mathrm{nd}) * * * *$ & $0 / 1$ \\
\hline Total & & & $71 / 76$ & $68 / 76$ \\
\hline
\end{tabular}

\footnotetext{
* number of positive samples by real-time PCR/ total number of tested samples

** Ct (cycle threshold): means of positive samples, each with three replicates

**** number of positive samples by conventional PCR/ total number of tested samples

*****not detected
}

but showed limitations in specificity and sensitivity (Trindade et al. 2007) and suitability for qPCR. Preliminary tests (data not shown) with the $\mathrm{SYBR}^{\circledR}$ Green detection system showed low efficiency and dimer formation when using these primers (Xcv1F/ 3R). Therefore, in this study, new primers were designed targeting new sites in the same pathogenicity gene sequence for use in real-time PCR. Like the previous set of primers, the new primers failed to show improved specificity. Despite being useful to differentiate species of Xanthomonas (Leite Junior et al. 1994b; Roberts et al. 1996), hrpB6 encodes an ATPase $(\mathrm{HrcN})$, involved in the assembly of the TTSS apparatus (Dunger et al. 2005), which is a conserved feature in Xanthomonas (Leite Junior et al. 1994a). Specificity tests with the new primers designed for the $\operatorname{hrp} B$ gene showed that, in addition to
Xcv, DNA from non-target Xanthomonas species and pathovars was also amplified. Trindade et al. (2007) also observed with Xcv 1F/3R primers DNA amplification of four strains of $X$. citri pv. mangiferaindicae and five strains of $X$. axonopodis pv. passiflorae. Since there are no reports of the natural occurrence of these pathovars affecting Vitis vinifera and considering that, in general, Xanthomonas species have a restricted host range, it is very unlikely that these results would limit their use for $\mathrm{Xcv}$ detection in grapevines and diagnosis of GBC. Primer pair Xcv18F/19R, although lacking high specificity towards Xcv, showed the highest efficiency and sensitivity when used in real time PCR compared to the other primer sets (data not shown). Furthermore, no amplification was detected with 41 bacterial strains from grapevine natural microbiota isolated from three different environments and varieties 
and neither with grapevine plant cell extract (Tables 1 and 2).

Searching for a more specific target, we used a genome-based approach to select additional annealing sites. Xcv is a non-pigmented xanthomonad and, to our knowledge, all strains collected in Brazil produce creamy-white colonies. Thus, primers targeting that feature would eliminate or minimize the risk of false negatives in diagnostic procedures.

Synthesis of the pigment xanthomonadin depends on the expression of a gene cluster. The whole genome sequencing of the pathotype strain LMG 965 (Midha and Patil 2014) showed some special features in that cluster responsible for the lack of pigmentation. Midha and Patil (2014) showed the occurrence of a fournucleotide deletion in the gene encoding the phosphotransferase/dehydratase enzyme in Xcv and an insertion element (IS) in pv. mangiferaindicae, which contains white strains as well. The Xpig primers were designed based on these differences, and our assays confirmed their specificity both in silico and in planta.

Preliminary tests using leaf extracts enriched with $\mathrm{Xcv}$ suspensions directly in the PCR tubes were not successful, possibly because of the presence of inhibitory compounds. These compounds, when present, affect PCR, via a direct effect on the polymerase or binding to the DNA (Palacio-Bielsa et al. 2009). Trindade et al. (2007) also observed that it was not possible to detect Xcv directly in infected plant extracts. BIO-PCR was used to overcome this problem. In addition, when compared to nested-PCR, BIO-PCR with $\mathrm{Xcv1F} / 3 \mathrm{R}$ primers was more sensitive for detecting $\mathrm{Xcv}$ in asymptomatic plants (unpublished results). Here, we combined BIO-PCR with the higher sensitivity of real-time PCR and more specific primers. Using total DNA extraction of samples artificially infected with Xcv did not impair sensitivity when compared with suspensions from pure cultures. The detection limits were the same, viz. $10^{3}$ (cPCR) and $10^{2} \mathrm{CFU} \mathrm{ml}^{-1}$ (qPCR). For other Xanthomonas spp., pathogenic on cassava, it was shown that a DNA purification step aided the diagnosis by concentrating DNA and eliminating PCR inhibitors, thus decreasing the detection limit (Flores et al. 2019). In our hands the highest sensitivity was obtained by combining bacterial population enrichment and real-time PCR. The total DNA extraction step, which is less time-consuming, may be more suitable for detecting Xcv in symptomatic material. In this case, high sensitivity would not be required because of the large bacterial population inside plant tissues. The choice of which method to use would greatly depend on lab resources, the number of samples to be tested and whether symptoms are evident or not. A duplex PCR with both sets of primers is also feasible, since both primers have the same sensitivity in cPCR. The two amplicons differ by $48 \mathrm{bp}$, so it would simply require gels with agarose concentration above $1.5 \%$ to separate and visualize both fragments by electrophoresis.

The detection limits of Xcv in extracts of leaves spiked with bacterial suspension were as low as $10^{1}$ CFU ml ${ }^{-1}$ when combining extract enrichment on the semi-selective NYDAM medium and qPCR, which has proven suitable for asymptomatic plant material. This is comparable to other real-time PCR protocols, such as the one employed for the detection of $X$. arboricola $\mathrm{pv}$. pruni in plum (Ballard et al. 2011). Previously, using leaf washes followed by plating, it was not possible to detect Xcv in $100 \%$ of the replicates at concentrations below $10^{5} \mathrm{CFU} \mathrm{ml^{-1 }}$ (unpublished results). With our newly developed real-time PCR method, Xcv was detected in all replicates, even at lower concentrations, when leaves were spiked.

The protocol was validated with field samples and both PCR formats, since the qPCR technique may not be accessible to many laboratories in Brazil. The results showed that our protocol can be used for the detection of $\mathrm{Xcv}$ in symptomatic and asymptomaticgrapevine samples and asymptomatic samples of alternative hosts. The presence of $\mathrm{Xcv}$ was detected by qPCR in $100 \%$ of symptomatic samples and $93.4 \%$ of the asymptomatic ones. For leaf samples, there was no difference between the techniques used for detection; that is, the positive samples by qPCR were also positive by cPCR. However, for the root samples, qPCR was more efficient, detecting the bacteria in all samples. Xcv colonizes grapevine plants systemically and could be detected in aerial plant parts, grape berries and seeds using light and scanning electron microscopy along with immunogold labeling, and a specific antibody (Tostes et al. 2014). In rootstocks Xcv has already been detected by isolation. Here we report its presence in the roots of a severely infected Red Globe vine. cPCR with Xpig primers followed by agarose gel electrophoresis confirmed the results in all leaf samples; however, for some samples with $\mathrm{Ct}$ above 27.0, DNA bands on agarose gels were less intense. 
The methods developed in this study proved to be useful for Xcv detection in asymptomatic samples and they could be valuable tools for the detection and identification of Xcv in different situations, both for research purposes and in quarantine routines, although they may not be suitable for large-scale monitoring programs where low cost, rapidity and portability are requirements (Chiriacò et al. 2018). The choice of method would depend on laboratory resources, and whether plant material shows symptoms or not. A suggested sequence for screening a large number of samples would be performing cPCR with the specific Xpig primers (low false positive rate), followed by confirmation of the negative samples with the more sensitive (low risk of false negatives), but costly and not specific qPCR. Isolation of the pathogen with further identification, including a pathogenicity test, should also be included in critical cases such as quarantine and trade issues.

Acknowledgments We thank the Brazilian National Council for Scientific and Technological Development (CNPq) and CAPESMEC for doctoral scholarships awarded to JGA Villela and CNPq for a research fellowship to MASV Ferreira (Grant \#310860/20164). The work was financed by Sistema Embrapa de Gestão (SEG), Projects: 12.13.06.011.00.00 - Management for bacterial canker and decline of grapevine in the São Francisco Valley and 02.13.03.006.00.00 - Developing of new cultivars to the viability and maintenance of Brazilian viticulture - Stage III.

\section{Compliance with ethical standards}

Conflict of interest The authors declare that they have no conflict of interest.

Informed consent All authors have reviewed the manuscript and approved its submission to European Journal of Plant Pathology.

\section{References}

Araújo, J. S. P., Reis Junior, F. B., Cruz, G. B., Oliveira, B. C., Robbs, C. F., Ribeiro, R. L. D., \& Polidoro, J. C. (2005). Production and characterization of polyclonal antibodies against Xanthomonas campestris pv. viticola. Pesquisa Agropecuária Brasileira, 40, 305-309.

Ballard, E. L., Dietzgen, R. G., Sly, L. I., Gouk, C., Horlock, C., \& Fegan, M. (2011). Development of a BIO-PCR protocol for the detection of Xanthomonas arboricola pv. pruni. Plant Disease, 95, 1109-1115.

Bull, C. T., \& Koike, S. (2015). Practical benefits of knowing the enemy: modern molecular tools for diagnosing the etiology of bacterial diseases and understanding the taxonomy and diversity of plant-pathogenic bacteria. Annual Review of Phytopathology, 53, 157-180.

Chiriacò, M. S., Luvisi, A., Primiceri, E., Sabella, E., De Bellis, L., \& Maruccio, G. (2018). Development of a lab-on-a-chip method for rapid assay of Xylella fastidiosa subsp. pauca strain CoDiRO. Scientific Reports, 8(7376). https://doi. org/10.1038/s41598-018-25747-4.

Doyle, J. J., \& Doyle, J. L. (1990). Isolation of plant DNA from fresh tissue. Focus, 12, 13-15.

Dunger, G. A., Arabolaza, A. L., Gottig, N., Orellano, E. G., \& Ottado, J. (2005). Participation of Xanthomonas axonopodis pv. citri hrp cluster in citrus canker and nonhost plant responses. Plant Pathology, 54, 781-788.

Ferreira, M. A. S. V., Bonneau, S., Briand, M., Cesbron, S., Portier, P., Darrasse, A., Gama, M. A. S., Barbosa, M. A. G., Mariano, R. L. R., Souza, E. B., \& Jacques, M.-A. (2019). Xanthomonas citri pv. viticola affecting grapevine in Brazil: emergence of a successful monomorphic pathogen. Frontiers in Plant Science, 10. https://doi.org/10.3389 /fpls.2019.00489.

Flores, C., Zarate, C., Triplett, L., Maillot-Lobon, V., Moufid, Y., Kanté, M., et al. (2019). Development of a duplex-PCR for differential diagnosis of Xanthomonas phaseoli pv. manihotis and Xanthomonas cassavae in cassava (Manihot esculenta). Physiological and Molecular Plant Pathology, 105, 34- 46. https://doi.org/10.1016/j.pmpp.2018.07.005.

Gama, M. A. S., Mariano, R. L. R., Silva Junior, W. J., Farias, A. R. G., Barbosa, M. A. G., Ferreira, M. A. S. V., et al. (2018). Taxonomic repositioning of Xanthomonas campestris pv. viticola (Nayudu 1972) Dye 1978 as Xanthomonas citri pv. viticola (Nayudu 1972) Dye 1978 comb. nov. and emendation of the description of Xanthomonas citri pv. anacardii to include pigmented isolates pathogenic to cashew plant. Phytopathology, 108, 1143-1153. https://doi.org/10.1094 /PHYTO-02-18-0037-R.

Hassankiadeh, A. A., Kazempour, M. N., Dehkaei, F. P., \& Rahimian, H. (2011). Detection of Xanthomonas oryzae pv. oryzae from rice seeds through Bio-PCR technique in paddy fields of Guilan province in northern Iran. Agricultura Tropica et Subtropica, 44, 71-76.

Janse, J. D., \& Wenneker, M. (2002). Possibilities of avoidance and control of bacterial plant diseases when using pathogentested (certified) or -treated planting material. Plant Pathology, 51, 523-536.

Kado, C. I., \& Heskett, M. G. (1970). Selective media for isolation of Agrobacterium, Corynebacterium, Erwinia, Pseudomonas and Xanthomonas. Phytopathology, 60, 969-976.

Katoh, K., Misawa, K., Kuma, K. I., \& Miyata, T. (2002). MAFFT: a novel method for rapid multiple sequence alignment based on fast Fourier transform. Nucleic Acids Research, 30, 3059-3066.

Kearse, M., Moir, R., Wilson, A., Stones-Havas, S., Cheung, M., Sturrock, S., \& Thierer, T. (2012). Geneious Basic: an integrated and extendable desktop software platform for the organization and analysis of sequence data. Bioinformatics, 28, 1647-1649.

Kim, B. K., Cho, M. S., Kim, M. H., Choi, H. J., Kang, M. J., Shim, H. S., Ahn, T.-Y., Kim, J., \& Park, D. S. (2012). Rapid and specific detection of Burkholderia glumae in rice seed by 
real-time Bio-PCR using species-specific primers based on an rhs family gene. Plant Disease, 96, 577-580.

Leite Junior, R. P., Egel, D. S., \& Stall, R. E. (1994a). Genetic analysis of $h r p$-related DNA sequences of Xanthomonas campestris strains causing diseases of citrus. Applied and Environmental Microbiology, 60, 1078-1086.

Leite Junior, R. P., Minsavage, G. V., Bonas, U., \& Stall, R. E. (1994b). Detection and identification of phytopathogenic Xanthomonas strains by amplification of DNA sequences related to the hrp genes of Xanthomonas campestris pv. vesicatoria. Applied and Environmental Microbiology, 60, $1068-1077$.

Lima, M. F., Ferreira, M. A. S. V., Moreira, A. W., \& Dianese, J. C. (1999). Bacterial canker of grapevine in Brazil. Fitopatologia Brasileira, 24, 440-444.

Llop, P., Caruso, P., Cubero, J., Morente, C., \& López, M. M. (1999). A simple extraction procedure for efficient routine detection of pathogenic bacteria in plant material by polymerase chain reaction. Journal of Microbiological Methods, 37, 23-31.

Loreti, S., Cunty, A., Pucci, N., Chabirand, A., Stefani, E., Abelleira, A., et al. (2018). Performance of diagnostic tests for the detection and identification of Pseudomonas syringae pv. actinidiae (Psa) from woody samples. European Journal of Plant Pathology, 152, 657-676.

Malavolta Junior, V. A., Almeida, I. M. G., Sugimori, M. H., Ribeiro, I. J. A., Rodrigues Neto, J., Pires, E. J. P., \& Nogueira, E. M. C. (1999). Occurrence of Xanthomonas campestris pv. viticola on grapevine in Brazil. Summa Phytopathologica, 25, 26-27.

Mavrodieva, V., Levy, L., \& Gabriel, D. W. (2004). Improved sampling methods for real-time polymerase chain reaction diagnosis of citrus canker from field samples. Phytopathology, 94, 61-68.

Midha, S., \& Patil, P. B. (2014). Genomic insights into the evolutionary origin of Xanthomonas axonopodis pv. citri and its ecological relatives. Applied and Environmental Microbiology, 80, 6266-6279.

Ministério da Agricultura, Pecuária e Abastecimento (MAPA). (2014). Normative Instruction $N^{\circ} 2$, of 6th February, 2014. Retrieved from http://www.agricultura.gov. br/assuntos/sanidade-animal-e-vegetal/sanidadevegetal/arquivos-prevencao/IN2_2014CancrodaVideira.pdf. Access date 09 July 2018

Palacio-Bielsa, A., Cambra, M. A., \& López, M. M. (2009). PCR detection and identification of plant-pathogenic bacteria: updated review of protocols (1989-2007). Journal of Plant Pathology, 91, 249-297.

Palacio-Bielsa, A., Cubero, J., Cambra, M. A., Collados, R., Berruete, I. M., \& López, M. M. (2011). Development of an efficient real-time quantitative PCR protocol for detection of Xanthomonas arboricola pv. pruni in Prunus species. Applied and Environmental Microbiology, 77, 89-97.

Parkinson, N., Cowie, C., Heeney, J., \& Stead, D. (2009). Phylogenetic structure of Xanthomonas determined by comparison of gyr B sequences. International Journal of Systematic and Evolutionary Microbiology, 59, 264-274.
Peixoto, A. R., Mariano, R. L. R., \& Viana, I. O. (2006). Semiselective medium for isolation of Xanthomonas campestris pv. viticola. Ciência Rural, 36, 1317-1320.

Robène, I., Perret, M., Jouen, E., Escalon, A., Maillot, M. V., Chabirand, A., \& Pruvost, O. (2015). Development and validation of a real-time quantitative PCR assay to detect Xanthomonas axonopodis pv. allii from onion seed. Journal of Microbiological Methods, 114, 78-86.

Roberts, P. D., Jones, J. B., Chandler, C. K., Stall, R. E., \& Berger, R. D. (1996). Survival of Xanthomonas fragariae on strawberry in summer nurseries in Florida detected by specific primers and nested polymerase chain reaction. Plant Disease, 80, 1283-1288.

Rodrigues Neto, J., Destefano, S. A. L., Rodrigues, L. M. R., Pelloso, D. S., \& Oliveira Junior, L. C. (2011). Grapevine bacterial canker in the State of Sao Paulo, Brazil: detection and eradication. Tropical Plant Pathology, 36, 42-44. https://doi.org/10.1590/S1982-56762011000100006.

Rozen, S., \& Skaletsky, H. J. (2000). Primer3 on the WWW for general users and for biologist programmers. In S. Krawetz \& S. Misener (Eds.), Bioinformatics Methods and Protocols: Methods in Molecular Biology (pp. 365-386). Totowa: Humana Press.

Schaad, N. W., \& Frederick, R. D. (2002). Real-time PCR and its application for rapid plant disease diagnostics. Canadian Journal of Plant Pathology, 24, 250-225.

Schaad, N. W., Cheong, S. S., Tamaki, S., Hatziloukas, E., \& Panopoulos, N. J. (1995). A combined biological and enzymatic amplification (BIO-PCR) technique to detect Pseudomonas syringae pv. phaseolicola in bean seed extracts. Phytopathology, 85, 243-246.

Schaad, N. W., Jones, J. B., \& Chun, W. (2001). Laboratory Guide for Identification of Plant Pathogenic Bacteria. St. Paul: APS Press.

Singh, D., Raghavendra, B. T., Rathaur, P. S., Singh, H., Raghuwanshi, R., \& Singh, R. P. (2014). Detection of black rot disease causing pathogen Xanthomonas campestris pv. campestris by BIO-PCR from seeds and plant parts of cole crops. Seed Science and Technology, 42, 36-46.

Tostes, G. O., Araújo, J. S. P., Farias, A. R. G., Frade, D. A. R., \& Olivares, F. (2014). Detection and cellular localization of Xanthomonas campestris pv. viticola in seeds of commercial 'Red Globe' grapes. Tropical Plant Pathology, 39, 134-140.

Trindade, L. C., Lima, M. F., \& Ferreira, M. A. S. V. (2005). Molecular characterization of Brazilian strains of Xanthomonas campestris pv. viticola by rep-PCR fingerprinting. Fitopatologia Brasileira, 30, 46-54.

Trindade, L. C., Marques, E., Lopes, D. B., \& Ferreira, M. A. S. V. (2007). Development of a molecular method for detection and identification of Xanthomonas campestris pv. viticola. Summa Phytopathologica, 33, 16-23. https://doi. org/10.1590/S0100-54052007000100002.

Vandroemme, J., Baeyen, S., Van Vaerenbergh, J., De Vos, P., \& Maes, M. (2008). Sensitive real-time PCR detection of Xanthomonas fragariae in strawberry plants. Plant Pathology, 57, 438-444.

Vincelli, P., \& Tisserat, N. (2008). Nucleic acid-based pathogen detection in applied plant pathology. Plant Disease, 92, 660 669. https://doi.org/10.1094/PDIS-92-5-0660. 